Journal of the German Oriental Society

Andhra History and Coinage (vols. 56, 57). Indian Kings named silāditya and the Kingdom of Mo-la-p'o (58). IndoParthian Dynasties (60). Sakas in Northern India (61). Identification of the Aśoka Pillar N.E. of Benares (63). Monolithic Pillars or Columns of Aśoka (65). Indian Travels of Apollonius of Tyana (68).

\title{
OTHER Journals
}

Indian Sculpture of the Gupta Period, A.D. 300-650 (Ostasiatischen Zeitschrift, Jahrg. iii, Heft i, 1914).

F. E. P.

\section{James Kennedy}

The Society has to mourn the loss of one of its old members in the death of James Kennedy. He was son of the Rev. James Kennedy of the London Missionary Society in North India, and was educated at the High School and University of Edinburgh. $\mathrm{He}$ passed the open competition for the Civil Service of India in 1862, and went out there the next year, being appointed to the North-West Provinces and Oudh (now called the United Provinces). Serving through all the grades of revenue and criminal administration, including land settlement, he became a Magistrate and Collector in 1884 and retired comparatively early in 1890 .

He then joined this Society in 1891, became a member of its Council in 1898, and was Treasurer from 1904 to 1917, and again for a short while in 1919 after the death of $\mathrm{Mr}$. Crewdson, who had succeeded him. Though he suffered from a severe malady of the eye for years, he was always most assiduous and genial in his duties, a most prudent custodian of the Society's purse. His health began to fail seriously early this year, and he died on June 20 at the age of 78 . 
James Kennedy was widely read in works on the history, religion, geography, and commerce of Asia and other Eastern subjects, and contributed many articles and notes to this Journal, as well as to the Asiatic Review and other periodicals. His notes elucidated minor points, and in his longer papers he brought abundant information together and discussed questions from an independent point of view, and his conclusions, based on much reading and study, helped towards the understanding of those questions.

His first papers were "Serpent Worship" (1891) and "The Early Commerce of Babylon with India" (1898), and notes dealt with the early Aryans $(1909,1915)$, the Periplus $(1913,1916,1918)$, and other points $(1900,1904$, etc.); but ancient Indian historical and religious questions interested him most. . His articles on the latter discussed them in connexion with Greek writings and Christian beliefs and doctrines, as in "Buddhist Gnosticism" (1902), "Hinduism and its debt to Nestorians" (1907), "The child Krishna and Christianity" (1907; also 1908), and "The Gospels of the Infancy, the Lalita-vistara and the Viṣnu Purāna " (1917). In history his important articles were "Indians in Armenia, 130 B.C. to A.D. 300" (1904); "The Secret of Kanișka" (1912; also 1913), which led to a discussion about that king's date, in which many scholars took part with great learning in 1913; and his last paper concluded this year, in which he set out his views regarding the Aryan invasion of Northern India.

His personal character and literary work were always attractive, animated with charm and humour, giving hearty appreciation to the labours of others, and, if dissenting, countering them with genial criticism.

F. E. P. 